\title{
Did imports of sweetened beverages to Pacific Island countries increase between 2000 and 2015?
}

\author{
Veronica Yueh Torng Lo ${ }^{1,2}$, Gary Sacks ${ }^{2}$ Emma Gearon ${ }^{2,3,4}$ and Colin Bell ${ }^{2^{*}}$ (D)
}

\begin{abstract}
Background: Nutrition-related chronic diseases are the major cause of illness and death in Pacific Island countries. Imports of sweetened beverages (SBs) are likely to be contributing but there is limited analysis of the quantities imported or the source countries of such beverages. The purpose of this study was to describe trends in the amount and types of SBs imported to Pacific Island countries and the impact of SB taxes on imports in Fiji and Tonga.

Methods: A repository of official international trade statistics was used to collect data on the volume, dollar value and source countries of SBs exported to Pacific Island countries from 2000 to 2015. Corresponding population data was sourced from the Secretariat of the Pacific Community for per capita analyses. We also explored which countries earned the most from exporting SBs to the Pacific. Descriptive and regression analyses were used to describe trends over time for each country and for the region as a whole.

Results: Imports of SBs to Pacific Island Countries from 2000 to 2015 increased by an average of $0.30 \mathrm{~kg}$ per person per year $(p<0.001)$. New Zealand and the USA were the largest income earners from SB exports to the Pacific over this period. The introduction of a tax did not impact the volume of SBs imported to Fiji. More data is needed to assess the impact of SBs tax on imports in Tonga.
\end{abstract}

Conclusions: Exports of SBs to Pacific Island countries are increasing. Both importing and exporting countries should consider the health implications of trade in these products.

Keywords: Imports, Pacific Island countries, Sugar sweetened beverage, Taxes, Trade, UN Comtrade, Fiji, Tonga

\section{Background}

In recent years, Pacific Island countries have experienced a rise in non-communicable diseases (NCDs). The region has some of the highest prevalence rates of type 2 diabetes $(47 \%)$ and obesity (75\%) in the world [1]. Moreover, 60 to 77\% of total deaths in Pacific Island countries are attributable to NCDs [1].

\footnotetext{
* Correspondence: colin.bell@deakin.edu.au

${ }^{2}$ Deakin University, Institute for Health Transformation, Global Obesity Centre, Geelong, Australia

Full list of author information is available at the end of the article
}

Globalisation, specifically the global trade of foods, may contribute to NCDs [2]. While trade has improved food security in developing countries, importation of processed foods and beverages that are nutrient-poor and/or energy dense such as soft drinks and instant noodles can contribute to unhealthy diets. This is particularly evident in Pacific Island countries where domestically produced foods low in fat and high in complex carbohydrate, dietary fibre, and foods of plant origin [3], have been largely replaced with imported, processed foods [4]. In Palau, for example 84\% of food supplies are imported [5]. This has led to a nutrition transition marked by increased availability of imported foods such as

(c) The Author(s). 2021 Open Access This article is licensed under a Creative Commons Attribution 4.0 International License, which permits use, sharing, adaptation, distribution and reproduction in any medium or format, as long as you give appropriate credit to the original author(s) and the source, provide a link to the Creative Commons licence, and indicate if changes were made. The images or other third party material in this article are included in the article's Creative Commons licence, unless indicated otherwise in a credit line to the material. If material is not included in the article's Creative Commons licence and your intended use is not permitted by statutory regulation or exceeds the permitted use, you will need to obtain permission directly from the copyright holder. To view a copy of this licence, visit http://creativecommons.org/licenses/by/4.0/ The Creative Commons Public Domain Dedication waiver (http://creativecommons.org/publicdomain/zero/1.0/) applies to the data made available in this article, unless otherwise stated in a credit line to the data. 
rice and bread and decreased consumption of local food such as taro and yam [1]. Seafoods have been replaced by imported meats high in fat and fruit and starches have been replaced by sugar and confectioneries $[1,6]$. Such dependence on imported foods, associated declines in domestic production, economic shocks and climate change are posing new threats to food security in the Pacific and contributing to NCDs [7].

Sugar sweetened beverages are defined as beverages that contain added sugars, or are a significant source of free sugars, such as soft drinks, energy drinks, juices and milk drinks. A study conducted in 2011 revealed high soft drink consumption, with 311 (L) being consumed per person in Tonga in 2011 and $84 \mathrm{~L}$ being consumed per person in Palau that same year [8]. In Tokelau, increased sugar availability has been associated with dental caries in children [9]. Between 1963 and 1999, sugar imports increased eight times and mean number of decayed and filled teeth increased from 3 to 5 [9].

Despite high rates of NCDs in the Pacific and our knowledge of the contribution of foods/beverages high in fat, sugar, and salt to NCDs, including caries, little research has been done to investigate volumes of unhealthy products imported to Pacific countries. International Trade Databases document the flow of goods, including foods, between countries and tapping into this information may help policy makers identify import trends detrimental to health.

The aim of this paper was to track imports of SBs to Pacific Island countries over time and identify source countries and related earnings. We also investigated the extent to which SBs imports decreased in Fiji and Tonga following the introduction of taxes in those countries.

\section{Methods}

\section{Study design}

We conducted a secondary analysis of publicly available food commodities data to describe changes in imports of sweetened beverages to Pacific Island countries between 2000 and 2015.

\section{Data sources}

The United Nations Commodity Trade Statistics Database (UN Comtrade) was used to collect information on the types and volume (or weight) of SBs imported to $\mathrm{Pa}$ cific Island countries, dollar value (in US dollars) and source countries from 2000 to 2015. The UN Comtrade has imports and exports information reported by statistical authorities from approximately two hundred countries or areas. It contains trade data from 1962 to the most recent year [10].

Pacific Island countries' population data from year 2000 to 2015 was sourced from the Statistics for Development Division (SDD) of the Secretariat for the Pacific
Community (SPC) and summed to give an estimate of the total population across all countries (Table 4 in Appendix 1) [11]. Where data was missing for a country in a particular year, the missing data was inferred using linear regression analysis of all available data points (between 2000 and 2015).

\section{Countries}

We focused on 12 countries that are members of the Pacific Island Forum Secretariat (PIFS), hereafter referred to as Pacific Island countries (PICs). These included Cook Islands, Federated States of Micronesia, Fiji, French Polynesia, Kiribati, New Caledonia, Palau, Samoa, Solomon Islands, Tonga, Tuvalu, and Vanuatu. Republic of Marshall Islands, Nauru, and Niue are also members of PIFS but import data were not available. Fiji and Tonga introduced SB taxes during the study period (Table 1). Average GDP for the12 included Pacific Island countries increased from USD 3.4 billion in 2000 to USD 8.9 billion in 2015 [12]. In 2015, GDP in Fiji was USD 4.6 billion and Tonga was USD 0.4 billion [12].

\section{Sweetened beverages}

We used the World Health Organization (WHO) nutrient profile model for the Western Pacific region to define SBs for this study [14]. This model was designed to assist countries in making decisions about appropriate marketing of food and beverages to children. It provides nutrient cut-points for sugar, salt, and saturated fat in 18 food categories above which it is not recommended that foods be advertised to children. The model uses the Harmonized Commodity Description and Coding System (HS code), an international standardised system of names and numbers for the classification of commodities, which is used by UN Comtrade. We defined SBs as HS Codes 20.09 (juices), 04.02 (milk drinks), 21.01.12 (tea and coffee), 22.02 (water, including mineral and aerated drinks) (Table 2; Table 5 in Appendix 2).

\section{Data analysis}

We conducted a linear regression analysis to describe trends in SB imports in kilograms per person per year for all 12 Pacific Island countries from 2000 to 2015. Upon visual inspection of the data, it was evident that an unusually large amount of SSBs were imported to Pacific Island Countries in 2010. After exploring stockpiling, slumps in domestic production, an increase in tourism, cyclones, and other potential explanations with colleagues in the Pacific we could not find evidence to explain the 2010 observation, and so we treated this as an outlier and removed 2010 values from the primary analysis. Sensitivity analyses including data for 2010 were not appreciably different to the primary analyses (Table 6 in Appendix 3). Descriptive analyses were 
Table 1 SB taxes introduced in Fiji and Tonga between 2000 and 2015

\begin{tabular}{|c|c|c|c|c|}
\hline COUNTRY & $\begin{array}{l}\text { YEAR OF } \\
\text { ADOPTION }\end{array}$ & IMPORT TARIFF RATE & EXCISE TAX RATE & SBs TAXED \\
\hline$\overline{F i j i}$ & 2011 & $\begin{array}{l}\text { No specific tariffa } \\
32 \% \text { import duty applied to } \\
\text { beverages whether or not they are } \\
\text { sweetened }\end{array}$ & $\begin{array}{l}\text { No specific tax } 15 \% \text { excise tax applied to } \\
\text { beverages whether or not they are } \\
\text { sweetened }\end{array}$ & $\begin{array}{l}\text { Soft drinks and juice, whether or not } \\
\text { sweetened, excludes sweetened milk } \\
\text { (HS22.02) }\end{array}$ \\
\hline Tonga ${ }^{b}$ & 2013 & $\begin{array}{l}\text { No specific tariff Average import } \\
\text { tariff of } 10 \% \text { on food and beverages }\end{array}$ & $\begin{array}{l}\text { T } 0.50 / L \text {, replacing an existing } 15 \% \text { import } \\
\text { duty }\end{array}$ & $\begin{array}{l}\text { Sweetened beverages, including } \\
\text { flavoured milk (HS22.02) }\end{array}$ \\
\hline
\end{tabular}

conducted to determine which countries were the top exporters of SB to Pacific Island countries based on earnings (US dollars). We used world consumer price inflation data (annual \% from 2000 to 2015) from the World Bank to adjust earnings for inflation (base year = 2015). Descriptive analysis was also used to determine trends over time in types of SBs (juices, milk drinks, tea and coffee, other) imported. To see if imports decreased following the introduction of taxes, we also conducted linear regression analyses to describe trends in SBs imports in kilograms per person per year for Fiji and Tonga.

\section{Ethics}

We applied for and were granted an exemption for ethics approval by the Deakin University Human Research Ethics Committee (2017-205).

\section{Results}

\section{Change in SB imports over time}

Imports of SBs to PICS increased from 24 million $\mathrm{kg}$ in 2000, to 39 million $\mathrm{kg}$ in 2015 (Fig. 1). Our regression analysis revealed a statistically significant increase of $0.30 \mathrm{~kg} /$ person per year $(95 \% \mathrm{CI}: 0.15,0.45)$ of SBs to PICs - or $4.5 \mathrm{~kg} /$ person (95\% CI: $2.25,6.75)$ over the 15 year period.

\section{Trends in imports of SBs by sub-category}

'Water, including mineral and aerated drinks' were imported in the highest volumes compared to other subcategories (Fig. 2). Between 2000 and 2015, we observed significant increases in imports per person per year of 'juices' (HS Code: 20.09), which increased by $0.18 \mathrm{~kg} /$ person per year (95\% CI: 0.12 to 0.23 ), 'tea and coffee preparations' (HS Code: 21.01.12), which increased by $0.01 \mathrm{~kg} /$ person per year (95\% CI: 0.00, 0.01), and 'water, including mineral and aerated drinks' (HS Code: 22.02) which increased by $0.15 \mathrm{~kg} /$ person per year (95\% CI: 0.05, 0.25). Imports of 'milk drinks' (HS Code: 04.02) per person per year did not significantly change over the period 2000 to $2015(-0.03 \mathrm{~kg} /$ person per year $(95 \% \mathrm{CI}$ : $-0.1,0.03)$.

\section{Top exporter earners from SBs}

The inflation adjusted total trade value of exports of SBs to the Pacific Islands was 1.1 billion in 2015 dollars, with New Zealand, USA and France being the top earning countries over this 15 -year period (Table 3 ).

\section{SBs imports to Fiji and Tonga}

We did not observe a statistically significant change in SB imports to Fiji between 2000 and 2015 (Fig. 3), average change of $0.11 \mathrm{~kg} /$ person per year (95\% CI: -.09 ,

Table 2 Sweetened beverage HS codes and description of the beverages they contain from the WHO Nutrient Profile Model

\begin{tabular}{ll}
\hline HS Codes $^{\mathrm{a}}$ & Description of beverages \\
\hline JUICES & \\
20.09 & $\begin{array}{l}\text { Fruit juices (including grape must) } \\
\text { whether or not containing added sugar or other sweetening matter }\end{array}$
\end{tabular}

MILK DRINKS

04.02

Milk and cream, concentrated or containing added sugar or other sweetening matter

TEA \& COFFEE

21.01.12

Preparations with a basis of extracts, essences, or concentrates with a basis of coffee

\section{WATER, INCLUDING MINERAL AND} AERATED DRINKS 


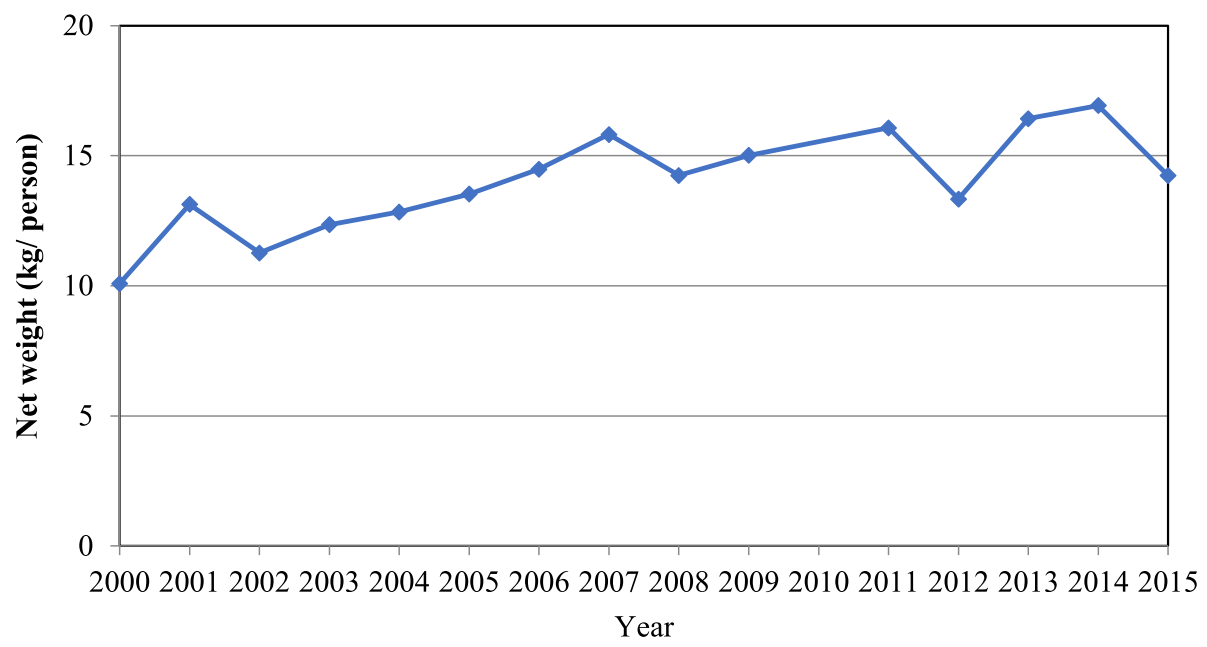

Fig. 1 SBs (kg/person) imported to Pacific Island countries from 2000 to 2015

0.32). We did not observe an obvious downward trend post the introduction of the 2011 SB tax when visually inspecting the trend. We observed a statistically significant increase in SB imports to Tonga between 2000 and 2014 , which increased by $1.50 \mathrm{~kg} /$ person per year $(95 \%$ CI: $0.87,2.14)$. It was not possible to draw conclusions on the effect of taxation in Tonga, given there was only one data point (2014) following the introduction of the tax.

\section{Discussion}

The quantity of SBs imported to PICs increased significantly from 2000 to 2015 with exporting countries, particularly New Zealand, the USA and France, making a total of USD 1.1 billion from sales. 'Water, including mineral and aerated drinks' were the most common type of SBs imported, and imports of juices, milk drinks and 'water, including mineral and aerated drinks' all increased significantly between 2000 and 2015 .

Liberalisation of trade barriers may be one explanation for the observed increase in SBs imports. A longitudinal analysis of 44 low- and middle- income countries describes trade liberalisation as a vector for sugar after observing lower tariffs translate into increased imports and increased sales over the 13 years from 2001 to 2014 [15]. Similarly, a study comparing sugar-sweetened carbonated beverage sales in Vietnam and the Philippines found growth in sales in Vietnam, led by foreign-owned companies, significantly accelerated after trade and investment liberalization [16]. Finally, a study in 11 PICs between 2003 and 2013 reported trade liberalisation had a positive and statistically significant effect on imports of processed foods to Pacific Island countries [17]. Our results are consistent with the study's findings over the same period of time. In addition to detrimental impact

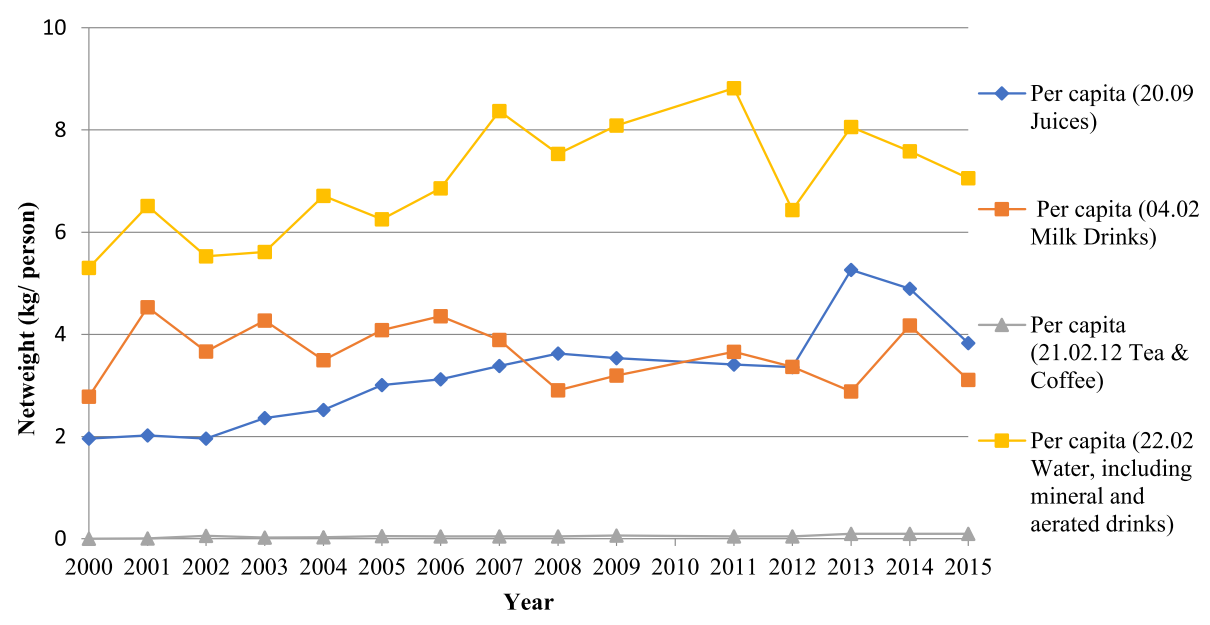

Fig. 2 SBs imported to PICs by sub-category between 2000 and 2015 
Table 3 Value of SB exports to Pacific Island Countries, 20002015 in 2015 dollars

\begin{tabular}{lll}
\hline Export Country & Trade Value (USD) $^{\mathbf{a}}$ & Share (\%) \\
\hline New Zealand & $197,514,296$ & 18.4 \\
USA & $153,067,437$ & 14.2 \\
France & $137,238,196$ & 12.8 \\
Australia & $63,819,822$ & 5.9 \\
Fiji & $22,192,803$ & 2.1 \\
Other countries & $501,154,671$ & 46.6 \\
Total & $1,074,987,225$ & 100
\end{tabular}

${ }^{a}$ Adjusted for annual world consumer price inflation

of diets high in processed foods on nutrition and health [18], a reliance on imports also has the potential to undermine domestic production and local food systems and loss of traditional knowledge and biodiversity [19].

Another explanation may be an increase in advertising for SBs. A study investigating the effects of unhealthy food advertising on children and adolescents in Suva, Fiji demonstrated an impact on food preferences and requests [20]. A further potential explanation is an association with development assistance. High levels of development assistance have been associated with high levels of food imports from the same countries. A survey of the availability of imported foods in Pacific Island countries found that $56 \%$ of food items in Nauru's stores were manufactured in Australia, a country that Nauru is heavily reliant on for aid [9]. Our data provides preliminary support for this contention given that New Zealand, Australia, France and the USA provide substantial development aid to Pacific Island countries, although more detailed analysis would be required to investigate it in a rigorous way.

This study addresses, in part, a lack of research evaluating the effectiveness of SB taxes in the Pacific Island region [21]. An assessment of the tax in Fiji revealed the cost of SBs increased in response to the tax [9]. It may be that the increase was not sufficient to impact imports, that a clear picture is being complicated by sizable domestic production of SBs in Fiji, or that our measure is too blunt to capture the impact of the tax on imports. In line with the decrease we observed in the imports of SBs to Tonga between 2013 (when the tax was introduced) and 2014, using a time series analysis, Teng et al. reported that successive tax increases from 2013 in Tonga were associated with increased prices, decreased taxed beverage imports, and increased locally bottled water [22].

\section{Strengths and limitations}

Strengths include the secondary analysis of publicly available commodities data for answering health related questions. We were also able to take advantage of natural experiments and track the impact of new SB taxes in Fiji and Tonga on levels of imported SBs. The UN Comtrade database has the sole purpose of providing trade data. However, it is not detailed enough to differentiate between particular types of SBs. For example, we were unable to exclude artificially sweetened beverages or bottled water from HS code 22.02. The proportion of water-based beverage imports to the Pacific that are artificially sweetened is not known but for comparison, it is estimated that non-sugar sweetened beverages comprised 36\% of water-based beverage sales in Australia in 1997 and 59\% in 2018 [23]. Also, it is continuously updated which means it may yield different data with

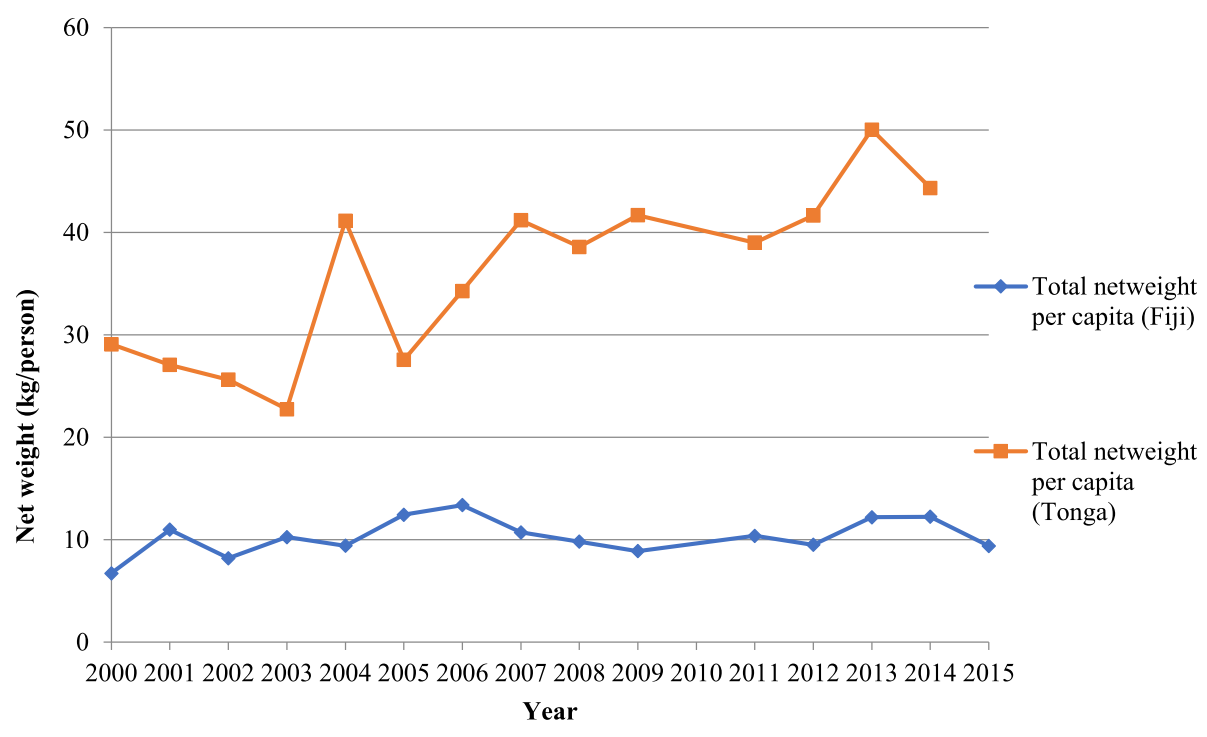

Fig. 3 Imports of SBs (kg/person) to Fiji and Tonga from 2000 to 2015 


\section{Appendix 1}

Table 4 Population data for all Pacific Island Countries of Interest

\begin{tabular}{|c|c|c|c|c|c|c|c|}
\hline Year & Fiji & Tonga & Tuvalu & Vanuatu & Samoa & Solomon Islands & Cook Islands \\
\hline 2000 & 798,751 & 99,162 & 9540 & 189,542 & 175,066 & 416,018 & 15,743 \\
\hline 2001 & 804,572 & 99,755 & 9576 & 194,605 & 176,710 & 427,804 & 15,030 \\
\hline 2002 & 810,335 & 100,238 & 9561 & 199,750 & 177,751 & 439,987 & 15,113 \\
\hline 2003 & 816,029 & 100,741 & 9682 & 204,985 & 178,683 & 452,555 & 15,193 \\
\hline 2004 & 821,637 & 101,265 & 9980 & 210,319 & 179,501 & 465,494 & 15,270 \\
\hline 2005 & 827,125 & 101,482 & 10,285 & 215,769 & 180,203 & 478,792 & 15,345 \\
\hline 2006 & 832,449 & 101,991 & 10,432 & 221,344 & 180,741 & 492,438 & 15,324 \\
\hline 2007 & 837,271 & 102,248 & 11,130 & 227,056 & 181,267 & 506,422 & 15,369 \\
\hline 2008 & 840,032 & 102,652 & 11,035 & 232,908 & 181,964 & 520,617 & 15,426 \\
\hline 2009 & 843,888 & 103,023 & 11,093 & 234,023 & 182,578 & 515,870 & 15,479 \\
\hline $2010^{c}$ & 847,793 & 103,365 & 11,149 & 245,376 & 183,123 & 539,469 & 15,529 \\
\hline 2011 & 851,744 & 103,036 & 11,206 & 251,784 & 187,820 & 553,254 & 14,974 \\
\hline 2012 & 856,571 & 103,192 & 11,183 & 255,678 & 187,812 & 562,307 & 15,964 \\
\hline 2013 & 859,200 & 103,300 & 10,900 & 264,700 & 192,203 & 615,804 & 16,049 \\
\hline 2014 & 865,602 & 103,131 & 11,449 & 266,905 & 189,991 & 586,379 & 16,134 \\
\hline 2015 & 867,000 & 103,300 & 11,300 & 277,600 & 187,300 & 515,870 & 16,219 \\
\hline $2016^{a}$ & & 100,651 & 11,534 & 272,459 & 195,979 & 651,700 & 17,459 \\
\hline Year & Federated States of Micronesia & French Polynesia & Kiribati & New Caledonia & Palau & Total Population ${ }^{\mathbf{b}}$ & \\
\hline 2000 & 107,021 & 259,530 & 84,230 & 208,708 & 19,129 & $2,382,440$ & \\
\hline 2001 & 106,840 & 260,190 & 85,872 & 212,825 & 19,293 & $2,413,072$ & \\
\hline 2002 & 106,612 & 260,850 & 87,396 & 216,941 & 19,454 & $2,443,988$ & \\
\hline 2003 & 106,339 & 261,510 & 88,756 & 221,058 & 19,610 & $2,475,141$ & \\
\hline 2004 & 106,021 & 262,170 & 90,272 & 225,174 & 19,761 & $2,506,864$ & \\
\hline 2005 & 105,654 & 262,830 & 92,533 & 229,291 & 19,907 & $2,539,216$ & \\
\hline 2006 & 105,232 & 263,490 & 93,698 & 233,407 & 20,047 & $2,570,593$ & \\
\hline 2007 & 104,754 & 264,150 & 95,470 & 237,524 & 20,162 & $2,602,823$ & \\
\hline 2008 & 104,217 & 264,810 & 97,201 & 241,640 & 20,278 & $2,632,780$ & \\
\hline 2009 & 103,620 & 265,470 & 98,989 & 245,757 & 20,397 & $2,640,187$ & \\
\hline $2010^{a}$ & 102,843 & 266,130 & 103,058 & 249,873 & 20,518 & $2,688,226$ & \\
\hline 2011 & 103,928 & 266,790 & 103,975 & 253,990 & 20,643 & $2,723,144$ & \\
\hline 2012 & 103,665 & 267,450 & 105,865 & 258,106 & 17,501 & $2,745,294$ & \\
\hline 2013 & 103,395 & 269,100 & 108,800 & 262,223 & 17,800 & $2,823,474$ & \\
\hline 2014 & 103,140 & 270,500 & 109,645 & 268,767 & 17,588 & $2,809,232$ & \\
\hline 2015 & 102,300 & 263,000 & 110,136 & 265,600 & 17,661 & $2,737,286$ & \\
\hline $2016^{c}$ & 104,600 & 273,800 & 115,300 & 277,000 & 17,800 & $2,912,915$ & \\
\hline
\end{tabular}

${ }^{\mathrm{a}}$ Data for the year 2016 was in linear trend analyses to make inferences about missing population data. Cells in which the population data for a specific year was inferred are presented in italics

${ }^{\mathrm{b}}$ Total population data represents the sum of all 12 countries.

c Data for the year 2010 was excluded from the primary analysis

successive data extractions. It should be noted that taxes in Fiji and Tonga apply to both sugar-sweetened and nonsugar sweetened beverages. Another limitation is the lack of information on domestic production which meant we were not able to fully quantify availability of SBs in some countries. Tonga has limited domestic production of SBs but Fiji has a Coca Cola Amatil factory that not only produces SBs for Fiji but also a number of other Pacific countries (see Table 3) [17]. A further limitation is that our population level analyses were not able to account for tourists who visit Pacific countries in large numbers and consume at least some of the imported SBs. 


\section{Appendix 2}

Table 5 SSB import data for PICs from 2000 to 2015

\begin{tabular}{llllllll}
\hline Year & $\begin{array}{l}\text { TOTAL } \\
\text { NETWEIGHT } \\
\text { JUICES } \\
(\mathbf{2 0 . 0 9 )}\end{array}$ & $\begin{array}{l}\text { TOTAL NETWEI } \\
\text { GHT MILK DRIN } \\
\text { KS (04.02) }\end{array}$ & $\begin{array}{l}\text { TOTAL NETWEIGH } \\
\text { T TEA AND } \\
\text { COFFEE (21.01.12) }\end{array}$ & $\begin{array}{l}\text { TOTAL NETWEIGHT WATER, } \\
\text { INCLUDING MINERAL AND } \\
\text { AERATED DRINKS (22.02) }\end{array}$ & $\begin{array}{l}\text { TOTAL NETWEI } \\
\text { GHT OF SB } \\
\text { IMPORTS (KG) }\end{array}$ & $\begin{array}{l}\text { NETWEIGHT OF } \\
\text { SB IMPORTS TO } \\
\text { FIJI (KG) }\end{array}$ & $\begin{array}{l}\text { NETWEIGHT OF } \\
\text { SB IMPORTS TO } \\
\text { TONGA (KG) }\end{array}$ \\
\hline 2000 & $4,672,566$ & $6,629,494$ & 1290 & $12,630,011$ & $24,025,113$ & $5,364,492$ \\
2001 & $4,884,104$ & $10,932,450$ & 7200 & $15,716,764$ & $31,688,888$ & $8,842,313$ & $2,884,047$ \\
2002 & $4,781,340$ & $8,954,690$ & 132,949 & $13,506,675$ & $27,535,113$ & $6,649,207$ & $2,568,555$ \\
2003 & $5,838,002$ & $10,569,714$ & 54,201 & $13,888,543$ & $30,560,474$ & $8,375,517$ & $2,291,880$ \\
2004 & $6,311,478$ & $8,757,039$ & 69,087 & $16,817,855$ & $32,182,719$ & $7,733,936$ & $4,164,337$ \\
2005 & $7,637,703$ & $10,362,393$ & 124,066 & $15,877,264$ & $34,344,225$ & $10,290,525$ & $2,796,673$ \\
2006 & $8,017,202$ & $11,195,688$ & 119,095 & $17,632,453$ & $37,236,289$ & $11,137,006$ & $3,497,240$ \\
2007 & $8,795,573$ & $10,131,184$ & 109,732 & $21,786,451$ & $41,169,794$ & $8,977,592$ & $4,211,572$ \\
2008 & $9,543,735$ & $7,653,258$ & 123,814 & $19,827,138$ & $37,499,351$ & $8,247,607$ & $3,961,497$ \\
2009 & $9,322,623$ & $8,436,547$ & 168,002 & $21,348,118$ & $39,648,951$ & $7,510,230$ & $4,293,835$ \\
$2010^{a}$ & $30,603,496$ & $9,236,683$ & 146,195 & $26,106,970$ & $66,423,182$ & $29,323,873$ & $4,412,428$ \\
2011 & $9,287,323$ & $9,959,137$ & 124,675 & $24,018,380$ & $43,808,565$ & $8,846,359$ & $4,018,894$ \\
2012 & $9,220,650$ & $9,227,892$ & 122,418 & $17,669,660$ & $36,616,978$ & $8,144,018$ & $4,297,561$ \\
2013 & $14,848,826$ & $8,135,919$ & 275,940 & $22,752,183$ & $46,367,487$ & $10,481,273$ & $5,168,096$ \\
2014 & $13,746,041$ & $11,726,753$ & 261,336 & $21,310,072$ & $47,573,716$ & $10,599,359$ & $4,573,153$ \\
2015 & $10,484,041$ & $8,508,732$ & 256,743 & $19,323,864$ & $38,966,734$ & $8,154,759$ & NA \\
\hline
\end{tabular}

${ }^{a}$ Data for the year 2010 was excluded from the primary analysis

\section{Appendix 3}

Table 6 Comparison of output for primary and sensitivity analyses

$$
\text { Primary Analyses (excluding data for the year 2010) Sensitivity Analyses (including data for the year 2010) }
$$

TOTAL SSB IMPORTS PER CAPITA

Increase per person per year $\quad 0.30(0.15,0.45)$

Increase per person over 15 years $4.50(2.25,6.75)$

\section{IMPORTS OF JUICES (20.09) PER CAPITA}

$p$-value $<0.001$

$p$-value $<0.001$

$2.70(1.80,3.45)$

\section{$0.38(0.05,0.70)$}

$5.70(0.75,10.50)$

$0.24(0.00,0.47)$

$3.60(0.00,7.05)$
$-0.03(-0.10,0.03)$

$$
-0.45(-1.50,0.45)
$$

$0.01(0.00,0.01)$

$0.15(0.00,0.15)$ $p$-value $=0.027$

$p$-value $=0.050$

$p$-value $=0.279$

Increase per person over 15 years $\quad-0.45(-1.50,0.45)$

$p$-value $<0.001$

$0.15(0.00,0.15)$

\section{IMPORTS OF WATER, INCLUDING MINERAL AND AERATED DRINKS (22.02) PER CAPITA}

$\begin{array}{ll}\text { Increase per person per year } & 0.15(0.05,0.25) \\ \text { Increase per person over 15 years } & 2.25(0.75,3.75)\end{array}$

Total IMPORTS OF SSBS TO FIJI PER CAPITA

Increase per person per year $0.11(-0.09,0.32)$

Increase per person over 15 years $1.65(-1.35,4.8)$

\section{Total IMPORTS OF SSBS TO TONGA PER CAPITA}

Increase per person per year

$1.50(0.87,2.14)$

Increase per person over 14 years

$21.00(12.18,29.96)$

$$
p \text {-value }=0.008
$$

$p$-value $=0.256$

$p$-value $=0.0002$
$0.16(0.04,0.28)$

$2.40(0.60,4.20)$

$0.29(-0.45,1.03)$

$4.35(-6.75,15.45)$

$1.52(0.93,2.12)$

$p$-value $=0.000095$ 


\section{Conclusions}

These results may help policy makers in the Pacific Island countries assess whether controls are needed on SB imports. Also, the results draw attention to the fact that tax payers in New Zealand and Australia are paying for the increasing costs of NCDs in the PICs (through aid funding provided to these countries) on the one hand while, on the other, companies based in New Zealand and Australia are profiting from exporting SBs to the same countries. For example, Tonga received AUD32.9 million ( USD 23.5 million) worth of aid from Australia in 2011-2012 [24]. In spite of the noted limitations of the UN Comtrade Database, its ability to shed light on imports of SBs to Pacific Island countries may have value for determining availability of other foods or food-groups contributing to NCDs.

\begin{abstract}
Abbreviations
AUD: Australian Dollar; Cl: Confidence interval; GACD: Global Alliance for Chronic Diseases; GDP: Gross Domestic Product; HS: Harmonised System or Harmonised Commodity Description and Coding System; NCD: Noncommunicable disease; NHMRC: National Health and Medical Research Council of Australia; PIC: Pacific Island Countries; PIFS: Pacific Islands Forum Secretariat; SDD: Statistics for Development Division of the Secretariat of the Pacific Community; SB: Sweetened beverages; SPC: Secretariat of the Pacific Community; UN Comtrade: United Nations Commodity Trade Statistics Database; USA: United States of America; USD: United States Dollar; WHO: World Health Organization
\end{abstract}

\section{Acknowledgments}

We acknowledge the support of Dr. Wendy Snowdon and staff at the Division of Pacific Technical Support, Western Pacific Region of the World Health Organization. We also acknowledge the assistance of the Secretariat of the Pacific Community and Deakin Library staff.

\section{Authors' contributions}

$V L$ drafted the initial manuscript and analysed and interpreted the results. EG performed the statistical analysis and, with GS, was a major contributor to writing the manuscript. CB conceptualised the study and was a major contributor to writing the manuscript. All authors read and approved the final manuscript.

\section{Funding}

This research was funded by Deakin University, Geelong, Victoria 3220, Australia. GS was supported by a Heart Foundation Future Leader Fellowship (102035) from the National Heart Foundation of Australia. He is also a researcher within NHMRC Centres for Research Excellence entitled Reducing Salt Intake Using Food Policy Interventions (APP1117300) and a Centre of Research Excellence in Food Retail Environments for Health (RE-FRESH) (APP1152968) (Australia). CB is a researcher on the NHMRC/GACD project titled Scaling up food policy and interventions to reduce noncommunicable disease in the Pacific Islands (APP1169322), an NHMRC partnership grant (RESPOND APP1132792) and Centre of Research Excellence in Food Retail Environments for Health (RE-FRESH) (APP1152968). The opinions, analysis, and conclusions in this paper are those of the authors and should not be attributed to the funders.

\section{Availability of data and materials}

Public access to the UN Comtrade database is available here. Public access to Population data for Pacific countries is available here. Our analysis of the data is available as supplementary material.

\section{Declarations}

\section{Ethics approval and consent to participate}

We applied for and were granted an exemption for ethics approval by the Deakin University Human Research Ethics Committee (2017-205).

\section{Consent for publication}

Not applicable.

\section{Competing interests}

The authors declare that they have no competing interests.

\section{Author details}

${ }^{1}$ Australian Bureau of Statistics, National Data Acquisition Centre, Melbourne, Australia. ${ }^{2}$ Deakin University, Institute for Health Transformation, Global Obesity Centre, Geelong, Australia. ${ }^{3}$ Monash Department of Clinical Epidemiology, Cabrini Institute, Malvern, Australia. ${ }^{4}$ Department of Epidemiology and Preventive Medicine, School of Public Health and Preventive Medicine, Monash University, Melbourne, Australia.

Received: 25 June 2020 Accepted: 2 March 2021

Published online: 20 May 2021

References

1. Estimé MS, Lutz B, Strobel F. Trade as a structural driver of dietary risk factors for noncommunicable diseases in the Pacific: an analysis of household income and expenditure survey data. Global Health. 2014 [cited 2020 Nov 07];10(1):48:15 Available from: https://globalizationandhealth. biomedcentral.com/articles/10.1186/1744-8603-10-48\#citeas DOl: https://doi. org/10.1186/1744-8603-10-48

2. World Health Organisation. Western Pacific Regional Plan for Noncommunicable Disease: A region free of avoidable NCD deaths and disability. World Health Organisation; 2009 [cited 2020 Nov 07]. Available from: http://mobile.wpro.who.int/noncommunicable_diseases/WHO_NCD_ RAP.pdf.

3. Shintani $\Pi$, Hughes CK. Traditional diets of the Pacific and coronary heart disease. Jour of Cardio Risk. 1994:1(1):16-20.

4. Sievert K, Lawrence M, Naika A, Baker P. Processed Foods and Nutrition Transition in the Pacific: Regional Trends, Patterns and Food System Drivers. Nutrients. 2019 [cited 2020 Nov 07];11(6). Available from: https://europepmc org/article/pmc/pmc6628317 DOl: https://doi.org/10.3390/nu11061328

5. McGregor A, Bourke RM, Manley M, Tubuna S, Deo R. Pacific island food security: situation, challenges and opportunites. Pac eco bullet. 2009 [cited 2020 Nov 07];24(2):24-42. Available from: https://core.ac.uk/download/pdf/1 56651824.pdf

6. Snowdon W, Thow A. Trade policy and obesity prevention: challenges and innovation in the Pacific Islands. Obesity reviews. 2013 [cited 2020 Nov 07]; 14:150-8. Available from: https://onlinelibrary.wiley.com/doi/full/10.1111/ obr.12090 DOl: https://doi.org/10.1111/obr.12090.

7. World Health Organisation. Food Secure Pacific Framework for Action. Food Secure Pacific Working Group; 2010.

8. Pak N, McDonald A, McKenzie J, Tukuitonga C. Soft drink consumption in Pacific Island countries and territories: a review of trade data. Pac Health Dialog. 2014;20(1):59-66.

9. Doherty MA, Blinkhorn AS, Vane ES. Oral health in the Pacific Islands. Int Dent J. 2010 [cited 2020 Nov 07];60(2):122-8. Available from https:// onlinelibrary.wiley.com/doi/abs/10.1922/IDJ_2242Doherty07 DOI: https://doi. org/10.1922/IDJ_2242Doherty07

10. United Nations. What is UN Comtrade?. United Nations; 2016 [cited 2020 Nov 07]. Available from: https://unstats.un.org/unsd/tradekb/Knowledgeba se/50075/What-is-UN-Comtrade.

11. Statistics for Development Division. Population Statistics 2018. Statistics for Development Division; [cited 2020 Nov 07]. Available from: https://sdd.spc. int/topic/population-statistics.

12. The World Bank. GDP (current US\$) - Pacific island small states. The World Bank; [cited 2020 Nov 07]. Available from: https://data.worldbank.org/indica tor/NY.GDP.MKTP.CD?end=2015\&locations=S2\&most_recent_year_desc=fa Ise\&start=1975.

13. McDonald A. Sugar-sweetened beverage tax in Pacific Island countries and territories: a disussion paper. Noumea, New Caledonia: The Secretariat of the Pacific Community; 2015. 60p. 
14. World Health Organisation. WHO Nutrient Profile Model for the Western Pacific Region: a tool to protect children from food marketing World Health Organisation; 2016 [cited 2020 Nov 07]. Available from: https://iris.wpro.who. int/bitstream/handle/10665.1/13525/9789290617853-eng.pdf.

15. Ana Mendez Lopez RL, Martin McKee, David Stuckler. Is trade liberalisation a vector for the spread of sugar-sweetened beverages? A cross-national longitudinal analysis of 44 low- and middle-income countries. Soc Sci Med 2017 [cited 2020 Nov 07];172:21-7. Available from: https://globalizationa ndhealth.biomedcentral.com/articles/10.1186/s12992-015-0127-7\#citeas DOl: https://doi.org/10.1186/s12992-015-0127-7.

16. Scharm A, Labonte R, Baker P, Friel S, Reeves A, Stuckler D. The role of trade and investment liberalization in the sugar-sweetened carbonated beverages market: a natural experiement contrasting Vietnam and Philippines. Glob Health. 2015:41.

17. Vakataki SV, Gani A. Trade policy and health implication for Pacific Islands countries. Int J of Soc Eco. 2017 [cited 2020 Nov 07] ;44(6):816-30. Available from: https://www.thelancet.com/article/S0140-6736(19)30041-8/fulltext\#\%2 O DOI: https://doi.org/10.1016/S0140-6736(19)30041-8.

18. Ashkan A, Patrick JS, Kairsten AF, Leslie C, Giannina F, Joseph SS, et al. Health effects of dietary risks in 195 countries, 1990-2017: A systematic analysis for the Global Burden of Disease Study 2017. Lancet. 2019 [cited 2020 Nov 07];393(10814):1958-72. Available from: https://www.thelancet. com/article/S0140-6736(19)30041-8/fulltext\#\%20 DOI: https://doi.org/10.101 6/S0140-6736(19)30041-8.

19. Englberger L, Lorens A, Guarino L, Taylor M, Snowdon W, Maddison M, et al. Pacific issues of biodiversity, health and nutrition. Pacific Health Dialog. 2007 [cited 2020 Nov 07];14(2):111-4. Available from: http://europepmc.org/abstra ct/MED/19588616

20. Hope SF, Snowdon W, Carey LB, Robinson P. 'Junk food' promotion to children and adolescents in Fiji. Fiji Jour of Pub Hea. 2013 [cited 2020 Nov 07];2(1):27-35. Available from: http://dro.deakin.edu.au/eserv/DU:30057949/ snowdon-junkfood-2013.pdf

21. Sacks G, Swinburn B. Taxation for NCD Prevention in the Pacific Department of Foreign Affairs and Trade. Department of Foreign Affairs; 2014. $7 \mathrm{p}$.

22. Teng A, Puloka V, Genç M, Filimoehala O, Latu C, Lolomana'ía M, et al, Sweetened beverage taxes and changes in beverage price, imports and manufacturing: interrupted time series analysis in a middle-income country. Int J Behav Nutr Phys Act. 2020 July [cited 2020 Nov 07];17(1):90. Available from: https://ijbnpa.biomedcentral.com/articles/10.1186/s12966-020-00980-1 \#citeas DOl: https://doi.org/10.1186/s12966-020-00980-1

23. Shrapnel W, Butcher B. Sales of Sugar-Sweetened Beverages in Australia: A Trend Analysis from 1997 to 2018. Nutrients. 2020 [cited 2020 Nov 07];12(4): 1016 Available from: https://pubmed.ncbi.nIm.nih.gov/32272711/ DOI: https://doi.org/10.3390/nu12041016

24. Department of Foreign Affairs. Tonga Department of Foreign Affairs and Trade. Department of Foreign Affairs [cited 2020 Nov 07]. Available from: https://www.dfat.gov.au/geo/tonga/Pages/tonga.

\section{Publisher's Note}

Springer Nature remains neutral with regard to jurisdictional claims in published maps and institutional affiliations.

Ready to submit your research? Choose BMC and benefit from:

- fast, convenient online submission

- thorough peer review by experienced researchers in your field

- rapid publication on acceptance

- support for research data, including large and complex data types

- gold Open Access which fosters wider collaboration and increased citations

- maximum visibility for your research: over $100 \mathrm{M}$ website views per year

At $\mathrm{BMC}$, research is always in progress.

Learn more biomedcentral.com/submissions 